\title{
$\mathrm{P}$

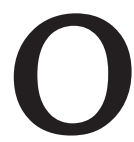 \\ e
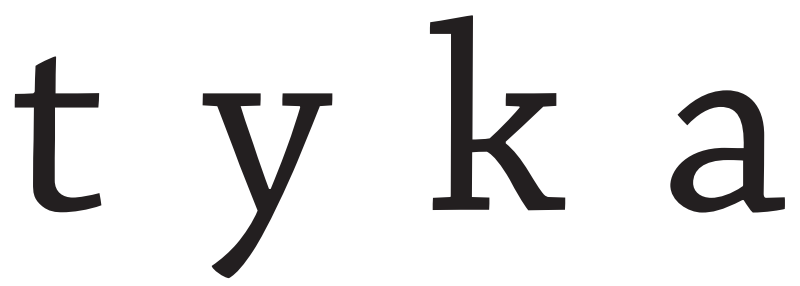 \\ transnarodowa Jahan Ramazani
}

\section{Poezja, nowoczesność, globalizacja}

Narrator poematu The Schooner „Flight” Dereka Walcotta, marynarz przezywany w dialekcie karaibskim Shabine ${ }^{1}$ ze względu na jasnobrązowy kolor skóry, w pamiętny sposób deklarował swoje międzyregionalne związki i dziedzictwo:

\footnotetext{
I'm just a red nigger who love the sea,

I had a sound colonial education,

I have Dutch, nigger, and English in me,

and either I'm nobody, or I'm a nation².
}

Shabine byłby „nikim”, gdyby warunek bycia kimś stanowiła przynależność do pojedynczej grupy kulturowej czy etnicznej; gdyby literacki głos był rozpoznawalny o tyle, o ile można mu przyporządkować kategorię narodowości; lub gdyby XIX-wieczny brytyjski historyk James Anthony Froude miał rację, pisząc o kulturowo i etnicznie zróżnicowanych Karaibach: „nie ma tam ludzi w prawdziwym znaczeniu tego słowa" ${ }^{3}$. Jednak w Walcottowskim manewrze z przydomkiem - niezwykle wymownym szyfrem poetyckiego „ja” przybieranym zarówno przez podstępnego Odyseusza, jak i Emily Dickinson czy Sylvię Plath - ów rzekomy „nikt” tryska cielesnością, cielesnością ulokowaną genetycznie w jego fikcjonalnym ciele przez holenderskich, afrykańskich i angielskich przodków, cielesnością rozmaitych narodowych i etnicznych literatur, którą bo-

\footnotetext{
${ }^{1}$ Shabine [slang] - używane głównie na Karaibach (w takich krajach, jak np. Dominika czy Saint Lucia) określenie osoby o jasnobrązowej skórze, najczęściej potomka lub potomkini mężczyzny rasy białej i kobiety rasy czarnej lub kobiety rasy białej i mężczyzny rasy czarnej [przyp. tłum.].

2 D. Walcott, The Schooner „Flight”, [w:] tegoż, Collected poems, 1948-1984, New York 1986, s. 346: „Jestem tylko czerwonym Murzynem, który kocha morze, / Odebrałem staranne, kolonialne wykształcenie, / Mam w sobie Holendra, Murzyna, Anglika, / I albo jestem nikim, albo jestem narodem”.

${ }^{3}$ J.A. Froude, The English in the West Indies; or, The Bow of Ulysses, New York 1887, s. 347.
} 
hater literacki inkorporuje ${ }^{4}$. Ten „nikt” składa się z wielości. Będąc zaś „narodem”, przypomina mnogi, nieredukowalny konglomerat nie w sensie społeczności zjednoczonej wspólnym pochodzeniem i językiem, zamieszkującej określone terytorium, jak w przypadku narodu Holendrów lub Anglików czy nawet - w rozszerzonym sensie - narodu panafrykańskiego. Reprezentując międzykulturową (cross-cultural) i międzyrasową (cross-racial) różnorodność, obwieszcza swe pluralistyczne więzi z Morzem Karaibskim i brytyjską edukacją podyktowaną zza morza. Jego ulokowana w basenie Morza Karaibskiego odyseja opowiedziana jest pentametrem jambicznym z rymami krzyżowymi i w standardowej angielszczyźnie, zakłócanej przez tamtejsze potrójne metrum wypowiedzi i karaibskie formy czasownikowe („who love the sea”). Kontrast pomiędzy rasistowskim, ordynarnym językiem użytym w odwołaniach do afrykańskiego dziedzictwa aczkolwiek dumnie przewartościowanego - a sformułowaniami w standardowej angielszczyźnie stosowanymi przy opisie jego europejskiej części, ukazuje dotkliwą dysproporcję sił pomiędzy kulturowymi półkulami, które w dykcji, gramatyce i ciele Shabine’a uległy zespoleniu. Pojąwszy, że nie wpasowuje się w tożsamościowe scenariusze ani białych osadników, ani czarnych nacjonalistów, Shabine ogłasza: „Nie dysponuję nacją - poza imaginacją”. Jak wskazuje ta gra słów, Walcott, podobnie jak wielu innych nowoczesnych i współczesnych poetów, postrzega poetycką wyobraźnię jako transnarodową, wykraczającą ponad naród siłę, która sięga poza granice terytorialne i normy prawne ${ }^{6}$.

Walcottowski Shabine nie jest bynajmniej pierwszą ani ostatnią z tych „zespolonych” figur XX-wiecznej poezji angielskiego kręgu kulturowego - by przywołać „pospólnego ducha, znajomego bardzo” (compound familiar ghost) T.S. Eliota, którego spektralny adres nie przez przypadek łączy w sobie elementy angielskie i amerykańskie, włoskie (terza rima) oraz irlandzkie (ponad pół tuzina nawiązań do Yeatsa) ${ }^{7}$. Narratorka na poły autobiograficznego Anglo-Mongrels and the Rose Miny Loy jest świadkiem dziwacznie komicznej relacji seksualnej pomiędzy ojcem - węgierskim Żydem a matką - angielską protestantką, która zaowocowała wydaniem na świat „skundlonego” potomstwa oraz

\footnotetext{
${ }^{4}$ Homer, Odyseja, Pieśń IX, domena publiczna, E. Dickinson, 288: I'm nobody! Who are you (Jestem Nikim! A ty?), przeł. S. Barańczak, „Zeszyty Literackie” 1989, nr 28, s. 65, S. Plath, Tulipany, przeł. J. Hartwig, [w:] Dzikie brzoskwinie. Antologia poetek amerykańskich, wybór J. Hartwig, przeł. J. Hartwig, S. Barańczak i in., Warszawa 2003, s. 125-128.

${ }^{5}$ D. Walcott, The Schooner „Flight”, dz. cyt., s. 350.

${ }^{6}$ Używam pojęcia „transnarodowy” jako określenia dla wierszy i innych tekstów kultury, które stylistycznie, topograficznie, intelektualnie bądź w inny sposób przekraczają granice narodów - w książce kładziony jest nacisk na pewne przykładowe grupy transnarodowych utworów poetyckich. Niektóre wiersze są w sposób bardziej oczywisty „transnarodowe” od innych - na przykład wiersze T.S. Eliota od wierszy Williama Carlosa Williamsa lub poezja Christophera Okigbo od poezji Okota p’Biteka. Dodatkowo nakładam to pojęcie na soczewkę hermeneutyki, przez którą obserwuję i badam przekraczające naród właściwości poezji. W tym sensie jeszcze szersza gama różnych typów poezji zorientowanej globalnie bądź lokalnie może ujawnić transnarodowe znamiona i powiązania. W moim użyciu „transnarodowego” kładę nacisk na wymiany i związki nie pomiędzy poszczególnymi podmiotami państwowymi, jak sugeruje czasem określenie „międzynarodowy”, ale w poprzek granic państw i narodów, regionów i kultur. Niemniej jednak idealne terminy nie istnieją używane w kontekstach: „transnarodowy”, „międzynarodowy”, „globalny”, „ziemski”, „kosmopolityczny”, „międzykulturowy (cross-cultural)”, „świat” oraz pokrewne, poprzez rozmaite odcienie znaczeniowe, mają wydobyć rozmaite aspekty ekstranarodowej poetyki, której badań się podjąłem. Podobnie niedoskonałego słownictwa używam do opisu międzykulturowych procesów, takich jak „hybrydyzacja”, „kreolizacja”, „interkulturyzacja”, „urdzennianie” (indigenization) itp. Definiuję i występuję w obronie „hybrydyzmu” w mojej książce The Hybrid Muse: Postcolonial Poetry in English, Chicago 2001, s. 179-184.

7 T.S. Eliot, Little Gidding, przeł. J. Niemojowski, [w:] tegoż, Wybór poezji, wybór tekstów K. Boczkowski, W. Rulewicz; wstęp W. Rulewicz, koment. K. Boczkowski, W. Rulewicz, przeł. K. Boczkowski i in., Wrocław 1989 ,

s. 312 .
} 
narodzinami jej „skundlonego” poematu ${ }^{8}$. Esej, będący zadaniem domowym w Theme for English B Langstona Hughesa, połączy afroamerykańskiego studenta i europejsko-amerykańskiego wykładowcę w dyskusji na temat dysproporcji sił, tak międzykulturowej jak skomponowana dwuwargowo lista ulubionych „nagrań - Bessie, bop, Bach” . „Czy jestem panią, czy niewolnicą / Pochodzę z Londinium czy z Nubii?” - pyta teatralnie „złożona” bohaterka Zuleika, afroromańska, czarnoskóra Brytyjka, bohaterka The Emperor's Babe Bernardine Evaristo ${ }^{10}$. To właśnie imię Marylin Chin - „Mei Ling” przepisane przez ojca poetki, emigranta z Chin zafiksowanego na punkcie amerykańskiej gwiazdy, jako „Marylin”, staje się metaforą rozszczepionej pomiędzy dwie półkule tożsamości w How I Got That Name - ponadpacyficznym poemacie splecionym z wątków chińskich i konfesyjnych, zaczerpniętych z europejskiego modernizmu oraz czarnego feminizmu ${ }^{11}$. Powyżsi międzykulturowi bohaterowie wraz z całą grupą innych uosabiają różnorodność transnarodowych poezji XX-wiecznych i późniejszych będących przedmiotem tej książki - od modernizmu Williama Butlera Yeatsa, Thomasa Stearnsa Eliota, Ezry Pounda, Miny Loy, Wystana Hugh Audena, poprzez renesans harlemski Claude’a McKaya, Jeana Toomera i Langstona Hughesa, twórczość północnoamerykańskich poetek tworzących po drugiej wojnie światowej - Elizabeth Bishop i Sylvii Plath, północnoatlantyckich poetów - Seamusa Heaneya, Tony’ego Harrisona i Paula Muldoona, współczesnych „rdzennych Amerykanów” - Dionisio D. Martineza i Li Younga Lee, „czarnoskórych Brytyjczyków” - Lintona Kwesi Johnsona i Bernardine Evaristo, aż po twórczość postkolonialnych afrykańskich, karaibskich i południowoazjatyckich poetów, takich jak Wole Soyinka, Lorna Goodison i Agha Shahid Ali. Pomimo że kreolizacja, hybrydyzacja i tym podobne są postrzegane często jako egzotyczny, wielokulturowy margines oficjalnych postępów w ramach poszczególnych historii literatur i odrębnych poezji narodowych, wspomniane dynamizmy międzykulturowe są prawdopodobnie siłą napędową poetyckiego, nowoczesnego i współczesnego rozwoju oraz innowacyjności.

Badanie poezji w kontekstach transnarodowych może się wydawać mało uzasadnione. Globalna mobilność innych form kulturowych, takich jak media cyfrowe i kino jest błyskawicznie dostrzegalna, zaś większość opracowań dotyczących literackiego kosmopolityzmu odnosi się do prozy - pewna badaczka stworzyła teorię kosmopolitycznej wspólnoty uczuć jako „wyobraźni narracyjnej”12. Poezja jest częściej postrzegana jako lokalna, regionalna, słowami Eliota: „uparcie narodowa”, a według Audena: „najbardziej prowincjonalna ze sztuk” ${ }^{13}$. Inny krytyk podsumowuje poezję jako „ekspresję i utrwalanie więzi lokalnych”, „nosiciela indywidualnych przywiązań: do matki, domu, ziemi ojczystej"14. Podczas gdy interdyskursywna i interkulturowa przepuszczal-

\footnotetext{
${ }^{8}$ M. Loy, Anglo-Mongrels and the Rose, [w:] tejże, The Lost Lunar Baedeker, red. R.L. Conover, J. Society, Highlands 1982, s. 109-172.

${ }^{9}$ L. Hughes, Theme for English B, [w:] tegoż, The Collected Poems of Langston Hughes, red. A. Rampersad,

D. Roessel, New York 1997, s. 410.

${ }^{10}$ B. Evaristo, The Emperor's Babe, London 2001, s. 201.

${ }^{11}$ M. Chin, How I Got That Name, [w:] tejże, The Phoenix Gone, the Terrace Empty, Minneapolis 1994, s. 16-18.

${ }^{12} \mathrm{M}$. Nussbaum, Cultivating Humanity, Cambridge MA 1997, s. 85-112. Dwa odmienne zdania na temat fabuły i kosmopolityzmu prezentują Rebeca Walkowitz w Cosmopolitan Style: Modernism beyond the Nation, New York 2006 i Timothy Brennan w At Home in the World: Cosmopolitanism Now, Cambridge MA 1997. Zob. także nacisk na narrację w dwóch wydaniach specjalnych opublikowanych w tym samym roku: Anglophone Literature and Global Culture, „South Atlantic Quarterly” 100, nr 3, 2001 i Globalizing Literary Study, PMLA 116, nr 1, 2001.

${ }^{13}$ T.S. Eliot, The Social Function of Poetry, [w:] tegoż, On Poetry and Poets, New York 1957, s. 8; W.H. Auden, Writing, [w:] tegoż, The Dyer's Hand and Other Essays, New York 1968, s. 23.

${ }^{14}$ R.E. Livingston, Glocal Knowledges: Agency and Place in Literary Studies, PMLA, 116, 2001, s. 150-151. Livingston wnikliwie analizuje teorie globalizacji.
} 
ność (porosity) prozy jest przedmiotem regularnych analiz, utwory poetyckie, a zwłaszcza lirykę postrzega się jako dziedzinę zwrotów kulturowo i psychologicznie skierowanych do wewnątrz, formalnie umocowaną w takich kanonicznych cechach, jak: zwięzłość, autorefleksywność, zwartość dźwiękowa, rytmiczność, afektywność i kunsztowność.

Według słynnego rozróżnienia Michaiła Bachtina cechami poezji są: „dośrodkowość”, ,jednorodność”, ,jedność i zamknięty charakter”, zaś strukturę powieści charakteryzują: dialogowość, dwugłosowość, różnojęzyczność i odśrodkowość ${ }^{15}$. Łatwo byłoby zakwestionować taki podział, przywołując kontrargumenty - sam Bachtin przyznawał, zwłaszcza odnośnie XX wieku - że jego klasyfikacja ulega rozmyciu, a XX-wieczną poezję postrzegał jako radykalnie sprozaizowaną ${ }^{16}$. Powszechna interkulturowość w poezji postkolonialnej i mniejszości etnicznych oraz antyromantyczność poezji modernistycznej i lingwistycznej w sposób naturalny podały w wątpliwość Bachtinowską definicję jednolitej, zsubiektywizowanej i monologicznej poezji. Jednak być może bardziej owocna od uchylenia tej teoretycznej antytezy okaże się próba przebadania, jak transnarodowe utwory w rodzaju Schooner „Flight” Walcotta sprzęgają ze sobą biegunowe przeciwieństwa. Ich cechą jest różnojęzyczność - często jednak zinternalizowana (np. poprzez - w autorefleksji Shabine’a - krzyżowanie dyskursu dialektu ze standardowym), a także psychokulturowe nakierowanie do wewnątrz - zgoda - ale rozproszone w międzykulturowej różnorodności (Shabine jako skupiony na sobie poeta i zarazem karaibska kolektywność). Wykazują one Bachtinowską intencjonalność dośrodkową (poeta staje się Shabine’em), której jednak przeciwdziała odśrodkowa siła kosmopolitycznego doświadczenia, aluzji i podróży. Paradygmat współwystępowania dośrodkowych i odśrodkowych dążeń poezji omija Scyllę ściśle poststrukturalnych modeli, w których wiersz jako dyskursywny kolaż jest wyssany z subiektywności, i Charybdę modeli nadmiernie podkreślających intencjonalność, w których wiersz jako wypowiedź prywatna zostaje zredukowany do autorskiego aktu mowy. Choć wiele transnarodowych wierszy poprzez swą zwartość, samoświadomość i dźwiękową gęstość reprezentuje „liryczność”, uwidacznia się w nich także Bachtinowska dialogowość, różnojęzyczność i hybrydyzm - ostatniego z wymienionych pojęć Bachtin używa na określenie literackiej mieszanki „wypowiedzi, stylów, języków i wartości" ${ }^{17}$. Międzykulturowa poezja od Eliota i Sterlinga Browna po Brathwaite'a, Muldoona i Grace Nichols nie może być redukowana do sugerowanej przez Bachtina lirycznej jednorodności - poeci zastępują ją przemieszczaniem się pomiędzy kodami dialektu i języka standardowego, zderzaniem mowy potocznej z wypowiedziami literackimi, inspirowaniem sobą wzajemnie gatunków rdzennych i obcych, łączeniem brzegów odległych lokalności, umieszczaniem jednych dyskursów w ramach innych, przysposabianiem zapożyczonych form, by mogły obejmować skrajności. Ponieważ skondensowanie poezji wymaga intensywnego zestawiania wykluczających się idiomów, pejzaży dźwiękowych, tropów i podgatunków, poezja - ulegająca sile tej konwergencji i rozszczelniająca się pod jej wpływem - umożliwia dokładny wgląd w to, jak międzykulturowe wektory globalnego modernizmu niekiedy współgrają, innym razem kolidują, a czasem kontrapunktują się wzajemnie. $Z$ tego powodu włączenie poezji do krytycznych debat na temat globalizacji może pomóc w skoncentrowaniu uwagi na skreolizowanej strukturze transnarodowego doświadczenia, które poezja formalnie i wyobrażeniowo ucieleśnia.

\footnotetext{
${ }^{15}$ M. Bachtin, Słowo w powieści, [w:] tegoż, Problemy literatury i estetyki, przeł. W. Grajewski, Warszawa 1982.

${ }^{16}$ Zob. M. Eskin, Bachtin on Poetry, „Poetics Today” 21, nr 2, 2000, s. 384-386.

${ }^{17} \mathrm{M}$. Bachtin, Słowo w powieści, dz. cyt., s. 133.
} 
Wierszem z lat 60., który sugeruje umocowanie poezji w „matce, domu i ziemi ojczystej”, jest Heavensgate Christophera Okigbo z inwokacją do lokalnej wschodnionigeryjskiej bogini rzeki zawartą w poniższym fragmencie:

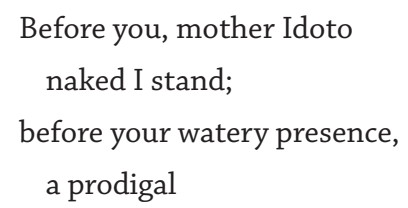

leaning on an oilbean,

lost in your legend $\mathrm{d}^{18}$.

Wiersz ten ukazuje wytęsknioną komunię z czczoną od pokoleń boginią wiejskiego strumyka płynącego nieopodal Ojoto, gdzie Okigbo dorastał - będącego częścią Biafry, za którą zginął w walce podczas nigeryjskiej wojny domowej w 1967 roku. Środki wykorzystane na okoliczność spotkania - podczas którego uniżony opiera się o totemiczne zachodnioafrykańskie drzewo (oilbean tree) należące do bogini - obejmują: obrazowanie wodnego odbicia, formuły zwrotów liryki drugoosobowej, symetrię dwóch pierwszych i dwóch ostatnich strof, epanalepsę w zwrocie „watchman for the watchword”, aliterację „leaning on an oilbean, / lost in your legend”. Poetyckie zasoby wiążą mówiącego z jego toponimicznie i botanicznie umiejscowionym światem. Wiersz może być odczytywany jako wypełnienie przez Okigbo przeznaczonej mu życiowej funkcji - objęcie odziedziczonych po dziadku kapłańskich powinności względem potoku Idoto.

Jak jak na ironię jednak, poetycka mitologizacja powrotu do korzeni jest poprowadzona okrężną drogą - poprzez zachodni modernistyczny synkretyzm i wiersz wolny, chrześcijańską opowieść o synu marnotrawnym oraz - w ostatnich dwóch wersach - język psalmów ${ }^{19}$ :

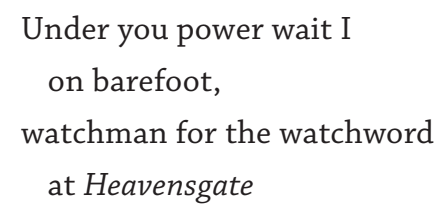

out of the depths my cry:

give ear and hearken... ${ }^{20}$.

\footnotetext{
${ }^{18} \mathrm{Ch}$. Okigbo, Heavensgate, [w:] tegoż, Labirynths, with Path of Thunder, London 1973, s. 3. „Przed tobą, matko Idoto / nagi staję; / przed twym wodnym jestestwem, / marnotrawny / oparty o oleiste drzewo, / zbłąkany w twej legendzie". Do książek krytycznych na temat poezji Okigbo zaliczają się: Critical Essays on Christopher Okigbo, red. U. Esonwanne, G.K. Hall, New York 2000 i Critical Perspectives on Christopher Okigbo, red.

D.I. Nwoga, Washington DC 1984. Dwoma pomocnymi esejami wprowadzającymi są: The Achievements of Christopher Okigbo Roberta Frasera ([w:] R. Fraser, West African Poetry, Cambridge 1986, s. 104-137) i The Poetry of Christopher Okigbo Davida Richardsa ([w:] Debating Twentieth-Century Literature, 1900-1960, red. R.D. Brown, S. Gupta, New York 2005. Korzystałem również z niepublikowanego manuskryptu Chukwumy Azuonye Christopher Okigbo at Work: Towards a Pilot Study and Critical Edition of His Previously Unpublished Poems, 1957-1967.

${ }^{19}$ „Usłysz, Panie, moje słowa, / zwróć na mój jęk uwagę; / natęż słuch na głos mojej modlitwy” (Psalm 5) i „Z głębokości wołam do Ciebie, Panie, / o Panie, słuchaj głosu mego! / Nakłoń swoich uszu” (Psalm 130).

${ }^{20} \mathrm{Ch}$. Okigbo, Heavensgate, dz. cyt., s. 3 (elipsa w oryginale): „Twej mocy oddany wyczekuję / bosy / jak strażnik na hasło / przy Heavensgate; / z głębokości wołam do ciebie / nakłoń uszu i wysłuchaj...”.
} 
Poprzez swą głęboką aluzyjność i pamięć formalną wiersz zarówno umiejscawia, jak i odmiejscawia podmiot. Mimo decyzji o powrocie do ojczyzny, przykłada on do politeizmu Igbo język monoteistycznej modlitwy, stosuje łacińskie inwersje składniowe i afrykanizuje modernistyczną koncepcję poezji jako intymnego rytuału werbalnego. Fragment ukazujący kapłańską ofiarę składaną lokalnej bogini jest także, według wprowadzającego komentarza Okigbo, orfickim poszukiwaniem kreatywnej siły poezji, którego domyślnym rezultatem jest właśnie czytany przez nas wiersz ${ }^{21}$. Skoro mówiący podmiot jest zarazem synem marnotrawnym, psalmistą, orfickim poetą i ofiarnikiem Igbo, to bogini, do której się zwraca - ukazująca się kolejno pod postaciami lwicy i syreny- jest bóstwem rzeki Igbo, Matką Ziemią, muzą, kulturą maternalistyczną, Eurydyką, Madonną oraz ukochaną. Okigbo trzyma w zanadrzu cały wachlarz poetyckich narzędzi, których źródła tkwią w Igbo, chrześcijaństwie, klasycyzmie i wysokim modernizmie. Podczas gdy Walcottowski Shabine eksponuje rażące kontrasty pomiędzy wykluczającymi się sferami jestestwa, ten podmiot spina bieguny bliskich i odległych odniesień poprzez poetyckie zastosowania muzycznych rezonansów, aliteracji i płynnej składni, pozostając w zgodzie z deklarowanym przez Okigbo poglądem, że jego europejskie, afrykańskie i inne dziedzictwa wzajemnie sobie nie zaprzeczają ${ }^{22}$. Pomimo tych różnic, i dla Okigbo, i dla Walcotta i dla wielu innych autorów poezja stanowi język będący w stanie pośredniczyć pomiędzy pozornie zastygłymi opozycjami lokalności i globalności, swojskości i obcości, poprzez zawieszenie czasem wykluczających roszczeń do prawdy w obrębie odmiennych systemów religijnych i kulturowych, zderzonych ze sobą przez kolonializm i nowoczesność oraz poprzez włączenie ich do gry.

Jeżeli nowoczesność jest „z natury rzeczy globalizująca”, jak ujmuje to Anthony Giddens, to XX- i XXI-wieczny udział poezji w procesach odbywających się w poprzek geograficznych i politycznych granic powinien być aksjomatyczny ${ }^{23}$. Jako katolicki Igbończyk albo igboński katolik, klasycznie wyedukowany i wychowany po afrykańsku, selekcjonujący w Nigerii manuskrypty na zlecenie Cambridge University Press, Okigbo żył i zbudował korpus swoich dzieł, opierając się na rozmaitych globalnych i ekskolonialnych, krzyżujących się porządkach - podobnie jak na swoje sposoby czynili to inni transnarodowi poeci od Pounda po Walcotta i od Loy po Chin. Mówiąc wprost, w nowoczesności globalna czasoprzestrzeń skurczyła się, ludzie podróżowali i migrowali częściej niż kiedykolwiek, technologia i systemy komunikowania umożliwiły wymianę idei, obrazów i głosów pomiędzy odległymi lokalnościami; imperia wprawiły w ruch swoje armie, religie, towary, kanony i artefakty; wojska rozpętywały konflikty na całym świecie, a kapitalizm „zglokalizował” produkty i usługi ponad granicami krajów. Globalizacja - rozumiana tutaj jako zjawisko mające za sprawą imperiów i handlu długą historię, ale w nowoczesności, a zwłaszcza w XX stuleciu gwałtownie rozpędzone ${ }^{24}$ jest pojemnym, amorficznym terminem, skupiającym rozmaite, odrębne, lecz nakładające się procesy, którego zróżnicowane aspekty są uwypuklane w poszczególnych modelach teoretycznych.

\footnotetext{
${ }^{21}$ Ch. Okigbo, Introduction, [w:] tegoż, Labirynths, dz. cyt., s. xi.

${ }^{22}$ M. Whitelaw, Interview with Christopher Okigbo (1965/1970), [w:] Critical Essays on Christopher Okigbo, dz. cyt., s. 55.

${ }^{23}$ A. Giddens, Konsekwencje nowoczesności, przeł. E. Klekot, Kraków 2008, s. 47.

${ }^{24}$ Tamże.
} 
Globalizacja jest często ukazywana jako jednokierunkowa homogenizacja i okcydentalizacja świata. W takim modelu akcentowana jest nieustępliwa asymetria ekonomicznych i politycznych sił w świecie oficjalnej dekolonizacji. Rzeczywiście, część poetów w swoim sprzeciwie na wymazywanie ich kulturowych światów uczyniła z poezji narzędzie oporu przeciwko spustoszeniom sianym przez (neo)kolonializm i nowoczesność, o czym przekonamy się w rozdziale szóstym. Już w Song of Lawino z 1966 roku, obszernym poemacie autorstwa Okota p'Bitek, mieszkanka aczolijskiej wioski - kobieta imieniem Lawino, uprzedzając antyglobalistyczny dyskurs, skarży się na wypieranie tradycyjnych afrykańskich praktyk przez zachodnie technologie, potrawy, tańce, religie i ideały piękna. Do swego męża - rozkochanego w białości, wypierającego się Afryki kierowcy mercedesa zwraca lament:

Listen, Ocol, my old friend,

The ways of your ancestors

Are good,

Their customs are solid

And not hollow....

I do not understand

The ways of foreginers

But I do not despise their customs

Why should you despise yours? ${ }^{25}$.

Ale Ocol jest już stracony - ucieleśnia całkowicie imperialistyczne nastawienie wobec wiejskiej kultury afrykańskiej, uznając ją za prymitywną i wsteczną. On i inni jemu podobni ubierają się, jak donosi Lawino:

As if they are in the white man's country.

At the height of the hot season

The progressive and civilized ones

Put on blanket suits

And woolen socks from Europe,

Long under-pants

And woolen vests,

White shirts;

They wear dark glasses

And neck-ties from Europe.

Their waterlogged suits

Drip like the tears

Of the kituba tree

After a heavy storm ${ }^{26}$.

${ }^{25}$ O. p'Bitek, „Song of Lawino” and „Song of Ocol”, London 1984, s. 41: „Stuchaj, Ocol, mój stary przyjacielu / Tryby twoich przodków / Sq dobre, / Ich zwyczaje sq pewne / A nie jałowe... / ................. / Nie pojmuję / Trybów cudzoziemców / Ale nie pogardzam ich zwyczajem / Dlaczego ty wzgardziłeś swoim?".

${ }^{26}$ Tamże, s. 45: „Jak gdyby byli w kraju białych ludzi. / W najgorętszej porze / Ci postępowi i cywilizowani / Nakładają ciężkie garnitury / I wełniane skarpety z Europy, / Długie kalesony, / Wełniane kamizele, / Białe koszule; / Noszą ciemne okulary / I krawaty z Europy. / Ich przemoczone garnitury / Kapią jak łzy / Z drzewa kituba / Po silnej burzy". 
Dokonane przez Lawino porównanie ociekających potem garniturów do „drzewa kituba / Po silnej burzy" jest ironicznym oswojeniem faktu, że jej mąż durzy się we wszystkim, co zachodnie. Okot - stanowczy obrońca afrykańskich kultur przed asymilacją z Zachodem - utrwala w czułym etnograficznym detalu pieśni, tańce, lekarskie i religijne praktyki egzystujących w wiejskiej kulturze Aczoli.

Pomimo tego, forma, układ i język jego długiego poematu jednak problematyzują postrzeganie poezji jako lokalnego czy narodowego środka oporu przeciwko hegemonicznej nowoczesności. Song of Lawino - stroniąc przecież od wełnianego kostiumu - łączy obszerny zachodni monolog dramatyczny wierszem wolnym z powtórzeniami i oralną spontanicznością aczolijskich pieśni; w poetyckiej dykcji słowa z języka aczoli i częściowo przetłumaczone przysłowia przeplatają się z topornie zafrykanizowaną angielszczyzną; antyzachodni regionalizm jest zasilany, jak na ironię, zachodnim antropologicznym wykształceniem Okota ${ }^{27}$. Literacki transnacjonalizm wiersza inspiruje dialog pomiędzy jednokierunkowym naporem zachodniej homogenizacji a argumentami adwokata lokalności. Wiersze tego typu poprzez swój język, formę i tematykę stanowią ekspresję i wyobrażeniową wersję rywalizacji sił globalizacji i regionalizacji, obcych wpływów i rdzennego oporu. W Omerosie, późniejszym długim poemacie, podejmującym temat ekonomicznej globalizacji, Walcott umieszcza w wulkanicznym piekle „zdrajców”, czyli oficjeli z lokalnego rządu, którzy „dostrzegli w tej ziemi widoki / z hoteli” i tym sposobem stali się wspólnikami przemysłu turystycznego w grabieży jego ojczystej Saint Lucii $^{28}$. A jednak Walcott przyznaje, że jego utwór ma także współudział w turystycznym wyzysku wyspy, jej malowniczego ubóstwa i okrutnej historii. Poeta jest niczym jego bohater, Philoctet, który na początku książki „uśmiecha się do turystów”, a za dodatkową opłatą „pokazuje im bliznę", emblematyczną dla ran niewolniczych pokoleńn ${ }^{29}$. Poemat zarazem powstaje w konflikcie współpracuje z globalną siecią, która naznacza jego ukochaną wyspiarską lokalność turystyczną monotonią, ale równolegle uczestniczy w narodzinach wyjątkowej syntezy zawartej w tym międzykulturowym eposie. Poemat, podobnie jak inne, w których dochodzi do konfrontacji między niesymetrycznymi, sprzecznymi światami, uwidacznia to, co Homi Bhabha określał jako „szczelinowe” (interstitial) - trzecią przestrzeń zrodzoną z wyobrażeniowych „negocjacji niewspółmiernych różnic”30.

Złożona struktura tych utworów udowadnia, że model homogenizującej globalizacji nie jest predysponowany do analizy poetyckiego wariantu transnacjonalności. Ponadto przyłożenie go do poezji i innych form kulturowych stwarza ryzyko metodologicznego powielenia totalizacji, którą w zamyśle potępia. Poezja obnaża uproszczenia w opinii Andreasa Huyssena, mówiącego że: „lokalne przeciwstawia się globalnemu jako autentyczna tradycja kulturowa, podczas gdy globalne funkcjonuje jako [...] siła alienująca, dominująca i dezintegrująca” oraz „że tylko lokalna kultura lub kultura jako lokalność jest dobra, autentyczna i trwała, zaś globalne formy kulturowe zasługują na potępienie jako manifestacje kulturowego imperializmu"31.

\footnotetext{
${ }^{27}$ Por. rozdział z mojej książki poświęcony poematowi: J. Ramazani, Hybrid Muse..., dz. cyt., s. 141-178.

${ }^{28}$ D. Walcott, Omeros, New York 1990, s. 289.

${ }^{29}$ Tamże, s. 3, 4.

${ }^{30}$ H.K. Bhabha, Miejsca kultury, przeł. T. Dobrogoszcz, Kraków 2000, s. 239.

${ }^{31}$ A. Huyssen, Geographies of Modernism in a Globalising World, [w:] Geographies of Modernism: Literatures, Cultures, Spaces, red. P. Brooker, A. Thacker, New York 2005, s. 9, 13.
} 
Tak radykalny paradygmat ukazuje „poszczególne kultury narodowe” jako coś, co Frederic Jameson nazywał „jednolitą siecią zwyczajów i praktyk, budujących totalność lub system”, do tego stopnia zagrożoną przez "jednostkową nowoczesność”, że niewielką pomocą będzie przebadanie dynamiki nachodzenia na siebie prądów oraz wymian w obrębie poetyckich form, gatunków i słowników, niezależnie od ewentualnych dysproporcji pomiędzy nimi ${ }^{32}$. Niuanse kulturowych napływów i odpływów rozmywają się, gdy przyjmujemy, że niezachodnia poezja i inne formy ulegają nieodwracalnemu „popsuciu” lub „rozpuszczeniu” na skutek wpływów zachodnich. W jednej z niewielu krytycznych prac dotyczących poezji i globalizacji Stephen Owen ubolewa nad mającą miejsce w modernizmie degradacją autentycznie "lokalnej” i "narodowej” poezji chińskiej do zhomogenizowanej „poezji świata” ${ }^{33}$. Podobnie autorzy Toward the Decolonization of African Literature utyskują, że modernizm wywiera na takich poetów jak Okigbo imperialistyczną presję i wpycha afrykańską literaturę oralną na tory reakcyjnej i egoistycznej twórczości z udziałem pisma ${ }^{34}$.

Jednak uważniejsze spojrzenie na transnarodową poezję wydobywa na jaw bardziej złożone schematy asymilowania się i stawiania oporu. Krytyka, która ostrzega zarówno przed globalizacją, jak i każdym poszczególnym wierszem jako tekstem w jego dosłownym znaczeniu czymś, co zostało utkane z czasem sprzecznych, a czasem współpracujących dyskursów, form, technik i ideologii - powinna raczej się zwrócić ku modelom dialogu czy uwikłania, zestrojonym z „rosnącym zakresem, intensywnością i prędkością globalnych współoddziaływań” i „pogłębiającym się splątaniem lokalności i globalności”35. Tego typu modele uwzględniają zarówno homogenizację, jak i heterogenizację, uniformizację i przeciwstawną dywersyfikację. Stuart Hall podkreśla, że siły „homogenizacji i przyswajania” oraz „lokalne praktyki oporu i kontestacji” ujawniają się „dokładnie w tym samym momencie”36. Taki wiersz jak Song of Lawino jest egzemplifikacją lokalnego oporu, ale - poprzez swój formalny i konceptualny hybrydyzm - stanowi także miarę przystosowania się i przemodelowania hegemonicznego jarzma, przeciwko któremu występuje. Według Arjuna Appaduraia, dla którego „zasadniczym problemem współczesnych relacji globalnych jest napięcie pomiędzy kulturową homogenizacją a kulturową heterogenizacją", przesadny nacisk na homogenizację uniemożliwia wzięcie pod uwagę, że „siły napływające z różnych metropolii do nowych społeczeństw są oswajane w ten czy inny sposób z co najmniej taką samą prędkością, z jaką do nich docierały: dotyczy to w tym samym stopniu muzyki i stylów budownictwa mieszkaniowego, co nauki i terroryzmu, widowisk i konstytucji" ${ }^{37}$. Okigbo urdzennia zachodnie formy poetyckie, by oddać hołd lokalnej bogince rzeki Igbo zamieszkującej nieopodal jego rodzinnej wioski, Okot natomiast przemodelowuje zachodni monolog, by udzielić literackiego głosu wiejskiej społeczności Aczoli. Obaj poeci unaoczniają to, co antropolog Ulf Hannerz miał na myśli, mówiąc

\footnotetext{
${ }^{32} \mathrm{~F}$. Jameson, Notes on Globalization as a Philosophical Issue, [w:] The Cultures of Globalization, red. F. Jameson, M. Miyoshi, Durham 1998, s. 63; tegoż, A Singular Modernity, New York 2002.

${ }^{33}$ Wyrażenie „ulegają popsuciu” zaczerpnąłem od Jamesona: Notes on Globalization..., dz. cyt., s. 63; S. Owen, World Poetry, „New Republic”, November 19, 1990, s. 28-32, zob. tegoż, Stepping Forward and Back: Issues and Possibilities for 'World' Poetry, „Modern Philology” 100, 2003, s. 532-548.

${ }^{34}$ O.J. Chinweizu, I. Madubuike, Toward the Decolonization of African Literature, Washington, DC 1983.

${ }^{35}$ D. Held i in., Global Transformations: Politics, Economics, and Culture, Stanford 1999, s. 2.

${ }^{36}$ S. Hall, The Local and the Global: Globalization and Ethnicity, [w:] Culture, Globalization and the World-System, red. A.D. King, London 1991, s. 34.

${ }^{37}$ A. Appadurai, Modernity at Large: Cultural Dimensions of Globalization, Minneapolis 1996, s. 32.
} 
o kulturowych przedsiębiorcach Trzeciego Świata, którzy „szperają i majsterkują” przy obcych formach, wytwarzając nowe, bardziej odpowiadające ich doświadczeniom - na wzór tego, co Janet Abu-Lughod określał „orientaliacją” zachodnich wpływów kulturowych ${ }^{38}$. W takim modelu globalizacji (zawdzięczającym swój kształt studiom postkolonialnym) kultura, jak opisuje to Revathi Krishnaswamy, nie jest postrzegana jako jedynie „unilinearna” transmisja, „ponieważ dynamizmy pomiędzy kulturowymi/geograficznymi regionami uwzględniają zawsze: selekcję, interpretację, przetłumaczenie, mutację i adaptację - procesy warunkowane przez takie pojęcia, jak «indygenizacja» $\mathrm{i}$ «wernakularyzacja» - a także kulturę-adresata, wnoszącą własne zasoby - na dialektyczną modłę, ponad kulturowy import" ${ }^{39}$. Kwame Anthony Appiah stwierdza, że homogenizując, globalizacja „jest w równym stopniu zagrożeniem dla homogeniczności”, ponieważ ludzie „wciąż wynajdują nowe formy różnicy: nowe fryzury, nowe slangi, a nawet, od czasu do czasu, nowe religie" - a także, moglibyśmy dodać, nowe rodzaje poezji ${ }^{40}$. Zauważywszy więc straty spowodowane przez globalizującą nowoczesność, możemy także rozpoznać, jak poeci - tworzący w dziedzinie szczególnie obfitującej w formalne i językowe tropy - skreolizowali i wyobrażeniowo przewartościowali globalne siły, by dać wyraz swojemu specyficznemu doświadczaniu zglobalizowanej lokalności i lokalizującej się globalności.

W przeciwieństwie do jednokierunkowego, homogenizującego modelu, transnarodowe prądy poezji można opisać jako poruszające się wahadłowo, wielokierunkowo lub, posługując się określeniem teoretyka kreolizacji Édouarda Glissant'a - ruchem pętli i powrotów (le retour et le détour $)^{41}$. Kamau Brathwaite zauważa, że jak na ironię, karaibscy pisarze dostrzegli w rytmach swej lokalnej mowy materię poetycką dzięki nie komu innemu jak T.S. Eliotowi, którego głos krążył po Barbados za pośrednictwem transmisji British Council - twórcy stawali się bardziej „rdzenni” poprzez równoległe rozwijanie waloru „nowoczesności”. W innej wymianie, odbywającej się między dwiema półkulami i analizowanej w piątym rozdziale tej książki, Ezra Pound odkrywa w haiku i innych wschodnioazjatyckich formach kulturowych możliwość przełamania impasu europejskiego symbolizmu na rzecz imagistycznej poetyki naturalnego obrazu, choć możliwe, że opierając się na twórczo naiwnym niedoczytaniu dalekowschodniej poezji jako niesymbolicznej ${ }^{42}$. Nie sugeruję bynajmniej, że globalne łącza transnacjonalizmów,

${ }^{38}$ U. Hannerz, Scenarios for Peripheral Cultures" i J. Abu-Lughod, Going Beyond Global Babble - oba artykuły w: Culture, Globalization and the World-System, dz. cyt., s. 124, 133.

${ }^{39}$ R. Krishnaswamy, Postcolonial and Globalization Studies: Connections, Conflicts, Complicities, [w:] The Postcolonial and the Global, red. R. Krishnaswamy, J.C. Hawley, Minneapolis 2008, s. 11. Odnośnie punktów styczności i rozbieżności między badaniami w naukach humanistycznych (postkolonializm) a społecznymi (globalizacja) zob. także: S. Gikandi, Globalization and the Claims of Postcoloniality, „South Atlantic Quarterly” 100, nr 3, 2001, s. 627-658.

${ }^{40}$ K.A. Appiah, Cosmopolitanism: Ethics in a World of Strangers, New York 2006, s. 101-103. Por. opis Appiaha, jak zagraniczne show telewizyjne przyswajane są w obrębie lokalnych kontekstów kulturowych, zmieniających ich znaczenia (s. 108-111) i przeciwstawną opinię Jamesona o globalnej „amerykanizacji bądź standaryzacji kultury, unicestwieniu lokalnych różnic” będących rezultatem eksportu amerykańskich programów telewizyjnych (F. Jameson, Notes..., dz. cyt., s. 57-58, 70).

${ }^{41}$ É. Glissant, Caribbean Discourse: Selected Essays, przeł. J.M. Dash, Charlottesville 1989, s. 14-26; tegoż, Le Discours antillais, Paris 1981, s. 28-36.

${ }^{42} \mathrm{Na}$ temat wczesnej wiary Pounda, że wschodnioazjatyckie obrazowanie poetyckie jest przedstawiające, niealuzyjne i wyzbyte konwencji zob.: M. Xie, Ezra Pound and the Appropriation of Chinese Poetry, New York 1999, s. 41, 69, 223. Obrony „niedoczytania” i „niezrozumienia” chińskiej poezji przez Pounda jako lektury produktywnej podjęła się Xiaomei Chen: Rediscovering Ezra Pound: A Postcolonial 'Misreading' of a Western Legacy, „Paideuma” 22, nr 2-3, 1994, s. 81-105 - ta i inne prace krytyczne dotyczące tematu zyskały pożyteczne podsumowanie [w:] E. Hayot, Critical Dreams: Orientalism, Modernism and the Meanind of Pound's China, „Twentieth-Century Literature” 45, nr 4, 1999, s. 511-533. 
u Brathwaite'a ukierunkowane na północ, zaś u Pounda na wschód, są tym samym: nagrania z „mroźnej Punocy”, które odsłuchuje Brathwaite, wyprodukowane zostały przez propagandowe ramię Imperium Brytyjskiego, natomiast przywłaszczenia przez Pounda minimalistycznej azjatyckiej techniki nie można potraktować jako niewinnego w obliczu amerykańskiego ekspansjonizmu ${ }^{43}$. Pomimo tych geopolitycznych rozbieżności, obaj poeci projektują poetyki reagujące lokalnie, paradoksalnie, poprzez rajd wokół globu. Znajdując pożywkę w międzynarodowej, wiecznie ewoluującej składnicy form, technik, gatunków i obrazów, poszczególne wiersze są ekspresją lokalności, a równolegle - formalnie, lingwistycznie i aluzyjnie zwracają się także w innych kierunkach. Być może najbardziej wyraziste XX-wieczne poetyckie świadectwo wschodnioafrykańskiego doświadczenia - Song of Lawino Okota - pośredniczy w przekazie życia aczolijskiej wioski częściowo dzięki reterytorializacji etnograficznej Pieśni o Hajawacie Longfellowa i biblijnej Pieśni Salomona ${ }^{44}$. Nawet gdy poeta powraca do lokalnych bądź regionalnych zdarzeń, wyobrażeń, języków i formalnych składowych poezji, przeplata je - zwłaszcza gdy jest mowa o globalizującej się nowoczesności - transnarodowymi elementami.

Przez swe dążenia do stworzenia teorii kategorii międzykulturowości w skali globalnej, orientalizm - koncepcja głosząca, że Wschód jest wytworem dyskursu, egzotycznym wobec Zachodu i jemu podporządkowanym - pomógł oświetlić istotną część wzajemnych stosunków Wschodu i Zachodu - czy też globalnej północy i południa ${ }^{45}$. Jednak niektóre zastosowania wczesnego paradygmatu transkontynentalnych studiów Edwarda Saida, dość przewrotnie, bagatelizują ponadgraniczne moce poezji i raczej utwierdzają, niż problematyzują granice tożsamościowe. Krytyka sprowadzająca wysoki modernizm i późniejsze międzykulturowe „przywłaszczenia” do orientalistycznej kradzieży lub prymitywnego egzotyzowania, niesie ryzyko ograniczenia zamiast otwarcia możliwości globalnej lub transnarodowej analizy ${ }^{46}$. Intelektualna rama zamkniętego i nieprzepuszczalnego systemu dyskursywnego, determinującego relacje Zachodu z orientem nie jest adekwatna - jak przekonuję w rozdziale piątym - do opisu przeciwstawnych napięć $\mathrm{w}$ obrębie zachodniego modernizmu, sugerowanych przez wiersze Yeatsa, Eliota, Pounda, w których kulturowo „obce” tworzywo bywa przyswajane częściowo lub fragmentarycznie i dzięki temu, przynajmniej w jakimś stopniu, zachowana zostaje możliwość zakwestionowania bądź rozszczelnienia kulturowej episteme ich tekstów. Jak pisze Dennis Porter, takie „przyciszone głosy i energie sprzeciwu wobec hegemonii” kwestionują „monolityczny” orientalizm ${ }^{47}$. Orientalizm nie jest także wydolnym modelem, jak zaryzykuję stwierdzić w rozdziale siódmym, do badania międzynarodowych (cross-national) aliansów, które Said - ostatecznie przeciwstawiający się ograniczeniom swojego wczesnego paradygmatu - analizował w obrębie poezji dekolonizacji. Tego typu przymierza, zawiązywane często

${ }^{43}$ E. [Kamau] Brathwaite, Calypso, [w:] tegoż, The Arrivants, New York, 1973, s. 49. Na temat amerykańskich ambicji Pounda zob. J. Nock-Hee Park, Apparitions of Asia: Modernist Form and Asian American Poetics, New York 2008, s. 23-56.

${ }^{44}$ K. Peterson, Okot p’Bitek, Interview, „Kunapipi” 1, nr 1, 1979, s. 89; An Interview with Okot p'Bitek, „World Literature Written in English" 16, 1977, s. 282-283.

${ }^{45}$ E. Said, Orientalizm, przeł. M. Wyrwas-Wiśniewska, Poznań 2005.

${ }^{46}$ Zob. na przykład: M. Torgovnik, Gone Primitive: Savage Intellects, Modern Lives, Chicago 1990 lub E. Marx, The Idea of a Colony: Cross-Culturalism in Modern Poetry, Toronto 2004. Por. także krytykę tego typu podejść [w:] M. Perloff, Tolerance and Taboo: Modernist Primitivism and Postmodernist Pieties, [w:] Prehistories of the Future: The Primitivist Project and the Culture of Modernism, red. E. Barkan, R. Bush, Stanford 1995, s. 339-354.

${ }^{47}$ D. Porter, Orientalism and Its Problems, [w:] Colonial Discourse and Post-Colonial Theory: A Reader, red. P. Williams, L. Chrisman, New York 1994, s. 153-154, 155. 
na linii Południe-Południe, były czasem zawierane ponad biegunowym podziałem świata, jak w przypadku twórczości takich poetów z Północy, jak Yeats, Allen Ginsberg, Tony Harrison i Joy Harjo, którzy wplatali swe doświadczenie w literatury i kultury Południa.

Być może najbardziej znanym i kontrowersyjnym przykładem artystycznego przywłaszczenia, dokonanego ponad linią podziału Północy i Południa, jest wkomponowanie przez Pabla Picassa afrykańskich masek i form w obraz Panny z Awinionu (1907). Praca ta jest słynnym odbiciem prymitywistycznych wizerunków i może być odczytywana jako estetyczna inscenizacja kolonialnego importu ${ }^{48}$. Równolegle jednak obraz rozrywa binarną opozycję wysokiej sztuki Zachodu i afrykańskiego folkloru, zaawansowanej techniki perspektywy zbieżnej i prymitywnego niefiguratywnego rękodzieła, oferując przy tym możliwość wyłonienia się nowych transkontynentalnych form, niewystępujących wcześniej ani w europejskich, ani afrykańskich estetykach. Jeśli jednym z probierzy takich transkontynentalnych splotów na wyboistym, globalnym terytorium jest to, czy odzwierciedlają dominującą ideologię, to innym - być może bardziej estetycznie skalibrowanym miernikiem - jest ich ewentualny potencjał do wykreowania świeżej kulturowej jakości, niezależnie od tego, czy o zasięgu lokalnym, czy globalnym. Pozostające bardziej złożonym uwikłanie poezji w kontrapunktowe rytmy i piętrzące się pejzaże, skreolizowane idiomy i zwernakularyzowane formy w wierszach Yeatsa czy Toomera, Lorny Goodison czy Aghy Shahida Alego, kwestionuje nie tylko krytyczne modele dyskursu-pułapki, lecz także - tym mniej wyrafinowane, im popularniejsze - kulturowe modele ukazujące świat podzielony na niemożliwe do pogodzenia fragmenty, między innymi jak w sugestii Samuela Huntingtona. Poetyckie sploty międzykulturowe ukazane w postaci Shabine'a, prezentującego się jako wielowymiarowy i ponadkontynentalny podmiot albo w inwokacji Okigbo wypowiadanej przez igbońsko-klasyczno-modernistycznego wyznawcę, dostarczają bardziej zniuansowany i wycieniowany obraz międzykulturowych zapożyczeń, podobieństw i wymian niż dychotomizująca i mechanicznie kawałkująca wizja „wielkich podziałów wśród rodzaju ludzkiego" i „zderzenia cywilizacji”" Ho Huntingtona. Światowe i transnarodowe studia nad poezją potrzebują, mówiąc w skrócie, dialogicznych alternatyw dla monologicznych modeli: tych, w obrębie których artefakt kulturowy jest synekdochą lokalnej bądź narodowej kultury narażonej na niebezpieczeństwo globalnego ujednolicenia; monolitycznej epistemologii orientu zamkniętej na zewnętrzne i wewnętrzne różnice; samowystarczalnej jednostki cywilizacyjnej pozostającej w ciągłym konflikcie z innymi.

Nie sugeruję wcale, że naród zniknie ze studiów nad poezją nowoczesną i współczesną, podobnie jak przepływ globalnego kapitału nie sprawia, że pojęcie państwa dezaktualizuje się w światowych analizach historii politycznej. Wyobrażenie i wypowiedzenie tożsamości narodowej (np. Jamajczyk lub Irlandczyk), subnarodowej (Biafranin lub Amerykanin z Dalekiego Wschodu) czy międzynarodowej (Panafrykanin, Karaibczyk) to potężne bodźce dla XXi XXI-wiecznej poezji. Louise Bennett, podająca w wątpliwość predyspozycje narodu i państwa jako telosu dla dekolonizacyjnego projektu, używa poezji, by ogłosić kreolskość sercem jamajskiej tożsamości. Choć silnie i świadomie zhybrydyzowana i międzynarodowa w swej genezie

\footnotetext{
${ }^{48}$ Por. wnikliwą krytykę afrykańskich przywłaszczeń Picassa w: S. Gikandi, Picasso, Africa, and the Schemata of Difference, „Modernism/Modernity” 2003, 10, nr 3, s. 455-480.

${ }^{49}$ S.P. Huntington, The Clash of Civilizations and the Remaking of Word Order, New York 1996.
} 
oraz w rezultatach, twórczość poetycka Yeatsa przyczynia się także do stworzenia nowej nazwy i mitologii narodu wyłaniającego się spod kolonialnych rządów. Jak stwierdza Pascale Casanova, pozycja wielu pisarzy może być postrzegana jako „podwójna, dwukrotnie zdefiniowana”, „nierozerwalnie narodowa i międzynarodowa” (choć jej europocentryczna rama dla światowej literatury być może zbyt silnie poddaje się narodowemu paradygmatowi) ${ }^{50}$. Poetycznym centrum Brathwaite'a są Karaiby, Okota - Afryka Wschodnia, Yeatsa zaś - Irlandia; jednocześnie ci i inni poeci za sprawą poetyckich, ideologicznych i innych globalnych obiegów współuczestniczą w transnarodowych imaginariach. Jak pisze Simon Gikandi, nawet „światowe teksty”, nawet jeśli „wzorcowe dla globalizacji”, ukazują „trwanie pojęcia narodu i państwa właśnie w tych utworach literackich, które miały ciążyć ku transcendującej kulturze globalnej”"51. Unieważnienie tych świeżo wyartykułowanych, mniejszościowych i postkolonialnych tożsamości dokonane pod spłaszczającym szyldem homogenicznej globalności byłoby wyjątkowo niefortunne - właśnie dlatego zwracam uwagę na ślady pozostawione przez transnarodowość i translokalność ${ }^{52}$. Jak pomagają mi dowieść w rozdziale siódmym prace Saida - częściowo poprzez przykład Yeatsa - można zauważyć intymną współzależność poezji i dekolonizacji. Wywód na temat elegii z rozdziału czwartego ukazuje, jak poetyckie struktury dźwiękowe i konwencje żałobne mogą wspierać nacjonalizm. Na ironię zakrawa jednak, że dysponująca tak długą pamięcią poezja - nawet ta przeraźliwie nacjonalistyczna - poprzez rytmy i tropy, schematy stroficzne i gatunkowe adaptacje jest uwikłana w złożone, międzynarodowe wątki. Za sprawą globalizacji poezja jeszcze bardziej rozszerza swój wyobrażeniowy zasięg wzdłuż horyzontalnych osi przestrzeni, a równolegle, w odróżnieniu od bardziej ulotnych i krócej oddziałujących mediów globalnych, uaktywnia także wertykalną - temporalną oś tropów, etymologii i form ponadnarodowego języka, który przeobraża. Wzajemnie oddziałujące kulturowe tropy, które przenikają do DNA poetyckich form i języka, sprawiają, że międzynarodowa, cząsteczkowa struktura poezji ujawnia swą narodową wyobrażeniowość, w imieniu której zdarza jej się przemawiać.

Gatunki poetyckie, takie jak epos, gazel czy elegia pastoralna, nie mówiąc o poszczególnych typach strof czy figurach retorycznych, od dawna znajdują się w transnarodowym obiegu i ulegają adaptacjom, ale napędzana nowoczesnością globalizacja przyspieszyła i zintensyfikowała te procesy. W nowoczesności, jak stwierdza Giddens w Konsekwencjach nowoczesności, poziom wzajemnych oddziaływań pomiędzy odległymi regionami jest „o wiele wyższy niż kiedykolwiek w poprzedzających ją okresach, a relacje zachodzące między lokalnymi a odległymi formami społecznymi i wydarzeniami uległy odpowiedniemu "rozciągnięciu»". Rozwijając tę obrazową metaforę, autor pisze: „Globalizacja odnosi się właśnie do tych procesów rozciągania, zachodzących w miarę, jak tryby nawiązywania połączeń między różnymi kontekstami społecznymi czy regionami zaczynają obejmować powierzchnię całego globu" oraz stwierdza, że „wydarzenia lokalne kształtowane są pod wpływem wydarzeń rozgrywających się w odległości wielu kilometrów i vice versa" ${ }^{33}$. Globalizację można zatem postrzegać jako utrwalającą i powielający dwubiegunowy „rozłam przestrzenny” imperium, skoro, jak zauważa Jameson, „to

${ }^{50}$ P. Casanova, Literature as World, „New Left Review” 31, 2005, s. 81.

${ }^{51}$ S. Gikandi, Globalization and the Claims of Postcoloniality, dz. cyt., s. 632.

${ }^{52}$ Moje użycie pojęcia „translokalności (nie globalności czy uniwersalności)” zawdzięczam Jamesowi Cliffordowi:

Routes: Travel and Translation in the Late Twentieth Century, Cambridge, MA 1997, s. 7.

${ }^{53} \mathrm{~A}$. Giddens, Konsekwencje nowoczesności, dz.cyt., s. 47. 
właśnie imperium rozciąga ścieżki ku nieskończoności, ponad brzegami i granicami państw", a sieci globalizacji jeszcze mocniej rozwijają się i ścieśniają te połączenia ${ }^{54}$. Według Jamesona: „kolonializm oznacza, że istotny element całościowej struktury systemu ekonomicznego jest ulokowany gdzie indziej”, zaś rozłączność ta odciska swoje piętno na „kognitywnym mapowaniu" literatury ${ }^{55}$.

Pisarze nowocześni, postkolonialni i inni angażują poetyckie zasoby do unaocznienia tej nie do końca uchwytnej rozciągłości przestrzennej. Faktycznie jest znaczącym zbiegiem okoliczności, że poetyckie użycia języka są często postrzegane jako jego „rozciąganie”. Elastyczność poezji - slalomy przestrzenne jej figur i aluzji, rytmiczne i dźwiękowe wyznaczanie współrzędnych dystansu, zawieszanie poznawalnych granic poprzez łańcuchy skojarzeń - dobrze sprawdza się w unaocznianiu powiązań między bardzo odległymi miejscami globalnej nowoczesności, od Ziemi jałowej Eliota i Murzyna mówiącego o rzekach Hughesa po W poczekalni Elizabeth Bishop i Hysterię Dionisio D. Martíneza, jak zobaczymy w rozdziale trzecim. Elektryczne przewody w The Powerline Incarnation Lesa Murraya zerwane $\mathrm{z}$ dachu i przekształcające ciało podmiotu (i wiersza) w tablicę rozdzielczą mogą być postrzegane jako egzemplifikacja i metafora poetyckiej elastyczności. W pospiesznych, pozbawionych interpunkcji, wypchanych geografią wersach góry spotykają się z równinami, australijskie farmy z miastami, a europejska muzyka klasyczna z amerykańskimi melodiami country:

I make a hit in towns

I've never visited: smoke curls lightbulbs pop grey

discs hitch and slow I plough the face of Mozart

and Johnny Cash I bury and smooth their song... ${ }^{56}$.

Zderzająca granice składnia i gramatyczne wyrzutnie Murraya uprzytamniają translokujący potencjał tkwiący zarówno w poezji, jak i w nowoczesności.

Translokalny zasięg poezji może być z łatwością dostrzeżony za sprawą nakładania na siebie map: u Eliota - Tamizy i okolic śródziemnomorskich oraz południowoazjatyckich, u Evaristo - Londinium i fragmentów południa globu skolonizowanego w późniejszych epokach przez Wielką Brytanię, u Heaneya - Irlandii i Jutlandii, a u Goodison - Jamajki i Irlandii, ale jest to również widoczne w poezji, która zdaje się konkretnie umiejscowiona. W ogłoszonym drukiem podczas drugiej wojny światowej South Parade Peddler Louise Bennett, posługując się językiem kreolskim i nazwą ulicy w Kingston, jednoznacznie sytuuje swoją handlarkę. Jednak w nowoczesności nawet „poeta narodowy” przy wnikliwym spojrzeniu okazuje się poetą transnarodowym. W tym przypadku globalny zasięg nowoczesnych wojen i relacjonujących ich systemów komunikacji rozszerza pole widzenia nawet silnie autochtonicznej

\footnotetext{
${ }^{54}$ F. Jameson, Modernism and Imperialism, [w:] F. Jameson i in., Nationalism, Colonialism and Literature, Minneapolis 1990, s. 51, 57. Pomimo zbieżności pomiędzy Jamesonem i Giddensem, należy zauważyć, że Jameson postrzega marksistowskie obramowanie jako nieprzystające do Giddensowskiej socjologii globalizacji i atakuje go jako „ideologa «nowoczesności»”. F. Jameson, A Singular Modernity, dz. cyt., s. 11.

${ }^{55}$ Tegoż, Modernism and Imperialism, dz. cyt., s. 50, 52.

${ }^{56}$ L. Murray, The Powerline Incarnation, [w:] tegoż, Learning Human: Selected Poems, New York 2000, s. 2021: „Uderzam w miasta / których nie odwiedzałem: kłęby dymu żarówki brzdęk szare / dyski tną się i zwalniają spinam twarz Mozarta / i Johnny’ego Casha grzebię i gładzę ich pieśń...”.
} 
poezji. Bennettowska przekupka, nakręcając się językiem agresji militarnej, ostrzega jednego z przechodniów, by zrobił u niej zakupy, bo inaczej „rozleci się jak Graf Spee” - niemiecki krążownik wysadzony na początku wojny przez kapitana załogi w Urugwaju nieopodal Montevideo. Pomysłowo przygaduje innemu rozrzutnikowi: „Tobie / dopiero włosy rozszabrowali!” i pyta innego „Torpeda spustoszyła panu szczękę / czy to sprawka pańskiej żony?”"57. Nie są to jedynie egzotyczne wzmianki, incydentalne i zewnętrzne wobec tekstu. W swej elastycznej materii utkanej z translokalnych gier słów, metafor i aluzji wiersz Bennett formalnie ucieleśnienia to, jak jamajska przestrzeń - zarówno realna, jak i wyobrażona - przesiąkała tak zwanym teatrem globalnej wojny. Co więcej, stychiczna, balladowa struktura utworu kreolizuje pochodzącą z Wysp Brytyjskich formę jamajską dykcją, ortografią i rytmami w procesie, który odwraca poprzednie wtargnięcia europejskiego kolonializmu w jamajską przestrzeń. W XX wieku nawet w silnie naznaczonych lokalnością wierszach ujawnia się skurczenie czasu i przestrzeni w transnarodowych obiegach i imaginariach.

$[\ldots]$

\section{Poetyka transnarodowa}

[...]

Być może zatem należałoby przyłożyć bardziej dekonstrukcyjne napięcie nie tylko do jednonarodowych narracji, ale także do rozróżnienia na autochtonów i kosmopolitów (aczkolwiek nie unieważniając go całkowicie), ponieważ zawiera ono w sobie ryzyko zatarcia transnarodowości „autochtonów” i sztucznego oddzielenia poetyki „kosmopolityzmu” od głównego, narodowo zdefiniowanego nurtu nowoczesnej i współczesnej poezji w języku angielskim. Wiersze nigeryjskich rówieśników - Wole Soyinki i Christophera Okigbo - były często zderzane z „tradycjonalistyczną”, „autentyczną” poezją innych afrykańskich pisarzy, takich jak Okot p'Bitek ${ }^{58}$, pomijano zaś fakt, że Soyinka i Okigbo urdzenniali modernizm za pomocą mitów Igbo i Joruby, konstrukcji składniowych oraz gier słów, zaś natywizm Okota jest zrośnięty (jak już wcześniej wspominałem) z jego zachodnim wykształceniem antropologicznym. $\mathrm{Na}$ Karaibach internacjonalizm Walcotta kontrastowany jest z lokalizmem kreolskich twórców, takich jak na przykład Louise Bennett, a pomija się, że Walcottowskie rytmy calypso kreolizują standardową angielszczyznę (Omeros rozpoczyna się słowami: „This is how, one sunrise, we cut down them canoes") ${ }^{59}$, podczas gdy ramę kreolskiej poezji Bennett, podobnie jak McKaya, stanowi strofa balladowa angielska - na przykład w jej wierszu Bans a Killin, w którym poetka porównuje jamajski angielski do innych dialektów legitymizowanych przez „de Oxford Book / A English Verse":

Dat dem start fi try tun language

From de fourteen century -

Five hundred years gawn and dem got

More dialect dan we! ${ }^{60}$

${ }^{57}$ L. Bennett, South Parade Peddler, [w:] tejże, Selected Poems, red. M. Morris, Kingston 1983, s. 83-84.

${ }^{58}$ Zob. np.: Ch.J. Onwuchekwa, I. Madubuike, Toward the Decolonization of African Literature, dz. cyt., s. 163, 259.

${ }^{59}$ D. Walcott, Omeros, dz. cyt., s. 3.

${ }^{60}$ L. Bennett, Bans a Killin, [w:] tejże, Selected Poems, s. 4-5: „Próbowali uzgodnić wspólny język / od czternastego stulecia - / pięćset lat przeminęło i teraz / mają więcej dialektów niż my!”. 
Bennett humorystycznie wyprowadza jamajski kreolski z peryferii i rekontekstualizuje go w perspektywie światowej jako jeden $\mathrm{z}$ wielu dialektów, które rozpleniły się podczas globalnej cyrkulacji języka. Podobnie w obrębie harlemskiego renesansu - przechodząc od transnarodowości do blisko związanej kwestii międzyetniczności (cross-ethnic) - euroamerykański warsztat Countee Cullena i Claude’a McKaya jest często stawiany w kontraście z bardziej „rdzennymi” praktykami Langstona Hughesa, a angloimagizm Jeana Toomera ze stylizacją na język mówiony Sterlinga Browna. Whitman, Sandburg i Robinson jednak stanowili wyraźne inspiracje także dla "autochtonów”, czego dowodzą ich użycia kolektywnego podmiotu oraz satyryczne rysunki postaci. Natomiast poezja „kosmopolitów”, włączając w to silnie aluzyjny i wielojęzyczny modernizm Harlem Gallery Melvina Tolsona, naznaczona jest afrykańską tradycją ustną wraz z jej uporczywym rymowaniem, przejaskrawioną ironią, retorycznym lawirowaniem i rozbuchaniem:

Convulsively, unexampledly,

Snakehips body and soul

Began to twis and untwist like a gyrating rawhide -

Began to coil, to writhe

Like a prismatic-hued python

In the throes of copulation ${ }^{61}$.

Nacjonalizm spod znaku ruchu Black Arts Amiriego Baraki, rezygnującego z przyswojenia europejsko-amerykańskich norm poetyckich, a w zamian celebrującego za to schematy bluesowe i jazzowe, może się wydawać opozycją wobec formalizmu takich zwolenników sonetu, jak Rita Dove, Robert Hayden i wczesna Gwendolyn Brooks. Jednak improwizatorska estetyka Baraki bazuje na spontanicznej poetyce bitników i twórców z kręgów Black Mountain College, którzy z kolei silnie inspirowali się jazzową czy bluesową improwizacją na znak protestu wobec formalnego ugładzenia i domknięcia - norm Nowej Krytyki (por. I Know a Man Roberta Creeleya i Kaddish Allena Ginsberga) ${ }^{62}$. Obecnie, gdy krytyka uwypukliła genealogiczną i etniczną swoistość korzeni nowoczesnej i współczesnej twórczości - nawet tej pozornie nieprzyporządkowanej do miejsca i rasy - być może przyszedł czas na bardziej aktywne zbadanie źródeł międzykulturowych i zasięgu poezji na przykład Baraki, Hughesa, Browna, Bennett czy Okota, sprawiającej wrażenie solidnie umocowanej w rdzennych tradycjach i lokalnym podłożu. W szerokim kontekście XX-wiecznych „podróżujących kultur” (sformułowanie Clifforda) i „uderzająco zdelokalizowanego świata” (określenie Appaduraia) poezje, które uznawaliśmy za rdzenne, regionalne czy lokalne, często okazują się mieć niezwykle zróżnicowany rodowód.

W dalszym ciągu jednak narodowość i etniczność mają do odegrania istotną rolę w przemodelowaniu nowoczesnej i współczesnej historii poezji. Trzeba ustrzec się przed uaktualnioną wersją uniwersalistycznego modelu „złotego skarbca”, który unieważnia narodowe i etniczne doświadczenie. Ani

\footnotetext{
${ }^{61}$ M. Tolson, Mu, [w:] tegoż, „Harlem Gallery” and Other Poems, red. R. Nelson, Charlottesville 1999, s. 263. „Konwulsyjnie, bezprzykładnie / ciało i dusza Wężych Bioder / zaczynają zwijać się i rozwijać jak wstęga surowej skóry - / zaczynają skręcać się, plątać / jak połyskujący barwami pyton / w kopulacyjnym znoju”.

${ }^{62} \mathrm{Na}$ temat międzyrasowych kontekstów u Baraki zob. A. Epstein, Beautiful Enemies: Friendship and Postwar American Poetry, Oxford 2006.
} 
lokalistyczna, ani uniwersalistyczna, nie nacjonalistyczna i nie bezmyślnie globalistyczna - translokalna poetyka eksponuje dialogiczne punkty przecięcia - czasem wytrwale stawiających opór, czasem jawnie asymilujących - specyficznych dyskursów, gatunków, technik i form o zróżnicowanej proweniencji. Umiejscowiona translokalnie, transnarodowa i międzyetniczna historia literatury odróżnia się w ten sposób od historii „postnarodowej” i „postetnicznej”, w ramach której postrzega się pisarzy (przy najogólniejszym zastosowaniu tych terminów) jako dryfujących w oceanie form i dyskursów pozbawionych narodowości i rasy. Globalizacja zaszła daleko, jednak stwierdzenie, że naród i państwo stanowią akceptowany anachronizm, marginalizuje dośrodkową siłę umiejscawiania oraz prądy kultur narodowych. Także paradygmat „internacjonalnego modernizmu”, sformułowany przez wcześniejsze, uznane pokolenie krytyków, takich jak Hugh Kenner i Richard Ellmann nie powinien być reaktywowany bez wprowadzenia korekty. Zawarty w nim internacjonalizm nie zawsze był przedstawiany w szczegółach, jego europocentryzm pozostawiał zbyt ciasną przestrzeń dla tak zwanego rozwijającego się świata, zaś postulowany uniwersalizm na ogół pozbawiał ethnosu pisarzy - na przykład żydowscy poeci byli rzadko uwzględniani lub opisywani jako tacy. A żydowskość może być pomocna w zrozumieniu obiektywistycznego, niemal sakralnego znaczenia słowa w Psalmie George’a Oppena:

The small nouns

Crying faith

In this in which the wild deer

Startle and stare out ${ }^{63}$

- lub jego odwrotności u poety nurtu Language, Charlesa Bernsteina, z jego satyrycznym rozładowywaniem niechęci wobec sztuki słowa, które można potraktować jako próbkę żydowskiego humoru:

Poetry services provide cost savings

$$
\begin{aligned}
& \text { to readers, such } \\
& \text { as avoiding hospitalizations (you're less likely }
\end{aligned}
$$

to get in an accident if you're home reading poems), minimizing

wasted time (condensare), and reducing

adverse idea interactions ${ }^{64}$.

Jednak narodowościowe lub etniczne dane opisowe, jakkolwiek pomocne, nie są same w sobie wystarczające, o czym świadczą różnice pomiędzy rewolucyjną retoryką Muriel Rukeyser a niechętną politycznym agitacjom poezją Oppena lub między konfesyjnością Adrienne Rich a antykonfesyjnością Bernsteina (umocowaną w kontynentalnym, poststrukturalnym sceptycyzmie wobec subiektywności). Międzykulturowa poetyka bazuje na tożsamościowych

${ }^{63}$ G. Oppen, Psalm, [w:] tegoż, New Collected Poems, red. M. Davidson, New York 2002, s. 99. „Skromne rzeczowniki / Głośno wyznają wiarę / W to, co spłoszyło jelenie / A czego one teraz wypatrują. [Przytaczany polski przekład wiersza autorstwa Artura Grabowskiego opublikowany został w piśmie „Europa” - dodatku kulturalnym do „Dziennika” z 11.05.2007 - przyp. tłum.] Na temat żydowsko-amerykańskiej poezji zob.: N. Finkelstein, Not One of Them in Place: Modern Poetry and Jewish American Identity, Albany 2001 i M.Y. Shreiber, Singing in a Strange Land: A Jewish American Poetics, Stanford 2007.

${ }^{64} \mathrm{Ch}$. Bernstein, The Lives of the Toll Takers, [w:] tegoż, Dark City, Los Angeles 1994, s. 23. „Usługi poetyckie gwarantują obniżkę kosztów / czytelników, takich / jak uniknięcie hospitalizacji (występuje mniejsze ryzyko / wypadku, kiedy siedzisz w domu i czytasz poezję), minimalizację / zmarnowanego czasu (condensare)

i ograniczenie / konfrontacji z wrogimi przekonaniami". 
paradygmatach, które sama komplikuje - polega na nich w swym tropieniu kultur literackich ulegających zacieraniu, ironizowaniu i przemodelowaniu.

Takie identyfikatory, jak „europejskość” czy „,angloamerykańskość” przytwierdzone do metod i narzędzi, które zostały potraktowane jako kulturowo przechodnie, także mogą się okazać pomocne. Na przykład etniczne obciążenie sonetu pomaga zrozumieć dokonane przez McKaya zdeponowanie złości i ambiwalentnych uczuć w formie, która umożliwia mu przemówienie, nawet jeśli równolegle pogłębia się jego kulturowa alienacja: „Zmuszony wieść życie ducha / Wśród synów ziemi byt osobny"65. O ile nie określimy konkretnie współrzędnych odniesień - czarnoskóry Jamajczyk imigrujący do Stanów Zjednoczonych i Europy, adaptujący klasyczną europejską formę poetyką - możemy przeoczyć silne napięcia w relacjach pomiędzy tymi punktami, które ujawniają się niekiedy w tego typu transkulturowych przedsięwzięciach. W Portrait in Georgia Jean Toomer w sposób wyrazisty przekształca metodę zestawień angloamerykańskiego imagizmu (zaczerpniętą częściowo ze źródeł dalekowschodnich) w narzędzie kodowania przemocy wewnątrz amerykańskiego doświadczenia rasizmu. Zamiast wywoływać wewnętrzny stan lub wrażenie, wiersz Toomera nakłada niemal heraldyczny opis twarzy białej kobiety na obraz linczu czarnoskórego mężczyzny:

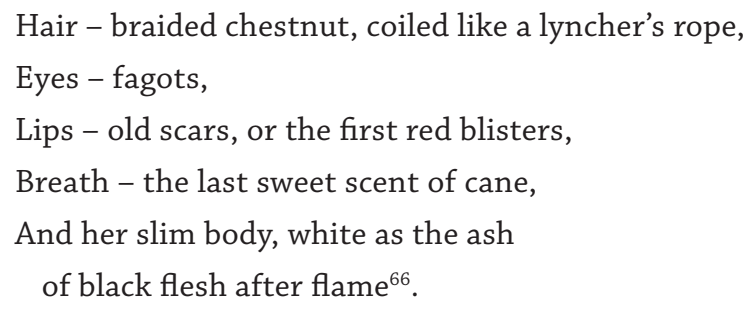

Gwałtowność imagistycznych zestawień, na przykład twarzy i płatków kwiatów u Pounda (In a Station of the Metro) albo sosen i morza u Hildy Doolittle (Oread) ulega silnemu przeakcentowaniu - otrzymuje społeczną i polityczną treść w kontekście przemocy, której doświadczali nękani Afroamerykanie. Toomerowskie zestawienia otwierają markowaną kolorem skóry szczelinę pomiędzy rasami i zarazem ją przekraczają - naruszają erotycznie nacechowaną granicę pomiędzy białym - kobiecym a czarnym - męskim ciałem, podkreślając przy tym różnice ich losów. Spektakl międzyrasowego połączenia odegrany wewnątrz wiersza - stanowiący poniekąd międzyetniczne spotkanie afroamerykańskiego poety z białym, usilnie przez niego rekonfigurowanym dziedzictwem - jest estetycznym splotem, dzięki któremu zapamiętane przez tekst historyczne tabu zostaje odrzucone. Wiersz Toomera, podobnie jak inne afrykańskie, amerykańskie i żydowskie przepisania europejskiej i białej, amerykańskiej spuścizny, wskazują, że rasa, etniczność i narodowość są niezbędnymi elementami międzykulturowych rozrachunków. Wyodrębnienie różnicy umożliwia oświetlenie interlingwistycznych, interkulturowych i interetnicznych napięć i tęsknot, napędzających współczesną i nowoczesną poezję.

${ }^{65}$ C. McKay, Outcast, [w:] tegoż, Completed Poems, red. W.J. Maxwell, Urbana 2004, s. 174.

${ }^{66} \mathrm{~J}$. Toomer, Portrait in Georgia (1923), [w:] tegoż, Cane: A Norton Critical Edition, red. D.T. Turner, New York 1998, s. 29. „Włosy - spleciony kasztan, ściśnięty jak sznur oprawcy, / Oczy - rózgi, / Wargi - dawne blizny albo czerwieniące się pęcherze / Oddech - ostatnia słodka wonność trzciny, / I jej wiotkie ciało, białe jak popiół / z czarnego mięsa strawionego ogniem". 
Mimo to w zbyt silnie narodowo lub etnicznie zorientowanych narracjach tkwi ryzyko niedoszacowania energii interkulturowych wymian i konfrontacji. W swojej nastawionej na szacunek lub lęk przed wpływem postawie jednokulturowe narracje dotyczące literackiej transmisji pomijają ironie wpływu (ironies of influence). Chociaż zamieszkujący faszystowskie Włochy Pound ostentacyjnie wyrażał swój antysemtyzm, jego obiektywistyczni spadkobiercy: Reznikoff, Oppen i Zukofsky to lewicowi, głównie nowojorscy Żydzi. Zukofsky, wyrażający się o Poundzie per „papa”, skorzystał z antysemickich metod poetyckich przy tworzeniu drugopokoleniowej estetyki modernistycznej, zawierającej elementy pieśni i humoru jidysz. W utworze Poem Beginning 'The' żartuje:

...mother

Assimilation is not hard

And once the Faith's askew

I might as well look Shagetz just as much as Jew ${ }^{67}$

Analogicznie Reznikoff, który zapożyczył od Pounda praktykę posiłkowania się historycznymi dokumentami, by skomponować swój Holocaust - obszerny, dokumentalny poemat powstały na kanwie procesów norymberskich i Eichmanna. Tak długo jak nasze sylabusy i historyczne narracje dotyczące nowoczesnej poezji nie staną się transnarodowe, będziemy narażeni na przeoczenia licznych ironii wpływu, takich jak ta, że Pound mógł stanowić podstawową inspirację dla żydowskich poetów od Zukofskiego po Ginsberga i Bernsteina; że imagistyczne zestawienia mogły pomóc Tommerowi w udramatyzowaniu binarnej struktury amerykańskiej przemocy rasowej; że „angielscy” poeci z kręgu Audena mogli przysposobić prawicowy katastrofizm „irlandzkiego" Yeatsa i „amerykańskiego” Eliota na cele swej lewicowej polityczności; że Gwendolyn Brooks mogła przekształcić nowokrytyczną estetykę kontrastu elokwencji i powściągliwości w celu zgłębienia społecznych ograniczeń afroamerykańskiej ekspresji; że urodzona w Hongkongu Marylin Chin mogła się posłużyć zaczepną, tożsamościowo zorientowaną poetyką feminizmu spod znaku Black Arts, by wyrazić amerykańskie wydziedziczenie azjatyckiej kultury; że urodzony na Kubie Dionisio D. Martinez mógł skorzystać z surrealistycznych przemieszczeń szkoły nowojorskiej, by dać wyraz dosłownym przemieszczeniom latynoskich imigrantów, że urodzony na Jamajce Linton Kwesi Johnson mógł się posiłkować afroamerykańskimi poetami przy tworzeniu swoich londyńskich „dubowych” i „reggaeowych” wierszy; że „etniczni” poeci ze Stanów Zjednoczonych pokroju Li-Younga Lee, Joy Harjo, Lorny Dee Cervantes i Alberto Ríosa, w tak prywatnych modelach, jak poezja konfesyjna czy Deep Image, odnaleźli sposób upamiętnienia kolektywnych historii kulturowych.

Eksponowanie transnarodowych i międzyetnicznych ironii jest, koniec końców, utwierdzaniem właśnie tych narodowych i etnicznych kategorii tożsamościowych, wobec których międzykulturowa poetyka chce się zdystansować. Postrzeganie poetów jako kreolizujących imagizm lub formalizm Nowej Krytyki, europejski modernizm lub feminizm spod znaku Black Arts wymaga przypisania tym pisarzom etniczności i narodowości. Reprezentowana przez nich estetyka jest każdorazowo rezultatem złożonych dziejów wcześniejszego procesu kre-

${ }^{67}$ L. Zukofsky, Poem Beginning 'The', [w:] tegoż, Complete Short Poerty, Baltimore 1991, s .17: „...matko / Asymilacja nie jest trudna / A gdy tylko Los się odmieni / Mogę równie dobrze wyglądać na szajgca, jak i Żyda”. 
olizacji. Ostatnio jednak proponowane alternatywy ryzykują jeszcze większy redukcjonizm. Potraktowanie „modernizmu” jako terminu ogólnego, który obejmuje przykładowo zarówno postkolonializm, jak i modernizm europejski, jest równoznaczne z zatarciem różnic pomiędzy ludźmi, kontynentami i historiami, upodobnieniem ich w homogenicznej masie XX- i XXI-wiecznych „modernistycznych” kultur. Poza tym postrzeganie ogółu literatur jako jednolicie "globalnych" niesie ryzyko unicestwienia specyfiki interkulturowych konfrontacji czy upodobnień. Używając często kwestionowanych terminów, takich jak „transnacjonalizm”, „hybrydyzacja” czy „kreolizacja” musimy sobie wciąż przypominać, że zlepione lub zestawione kultury, miejsca i tożsamości są konglomeratami zróżnicowanych motywów - choć konwergentne rezultaty tych zderzeń były często naturalizowane w sposób, który pozbawił je potencjału zaskoczenia lub ironii. Hybrydyzmy najnowszych postkolonialnych i międzyetnicznych literatur mogą rzeczywiście pomóc w odzyskaniu wcześniejszych hybrydyzmów - modernizmu europejskiego czy renesansu z Harlemu, a te z kolei mogą się przyczynić do przywrócenia świadomości o jeszcze wcześniejszych momentach kultury.

Salman Rushdie, celebrując „hybrydyzmy, domieszki, melanże - przemian[ę], która bierze się z nowych i nieoczekiwanych kombinacji”, dostrzega, że „miszmasz, galimatias, trochę tego $i$ trochę owego - oto w jaki sposób nowe wkracza do świata"68. Kiedy śledzimy meandry transnarodowego dziedzictwa, natykamy się na opowieści, w których - według Eliota - jest „wiele skrytych przejść, wiele tajemnych / Korytarzy i progów”69. Wytropienie tych skomplikowanych, interkulturowych relacji, które były nawiązywane w poprzek granic państw i etniczności, bez wymazywania tych granic i ulokowanych w nich wcześniej hybrydyzmów, stanowi początek wyjaśniania, jak poezja pomaga nowemu wkroczyć do świata.

Poprzez swoje terytorialnie i narodowo sprofilowane kawałkowanie świata dyscypliny humanistyczne przyczyniały się często do umacniania - aczkolwiek zgodnie ze swoimi kompetencjami - narodowych i cywilizacyjnych granic. „Milczący bądź wyartykułowany literacki nacjonalizm pisze Meredith McGill - nadal wyznacza porządek organizacyjny wydziałów anglistyki - pomimo faktu, że językowe i demograficzne ciągłości, podobnie jak złożone, przenikające się koleje publikowania i dzieje form literackich przeczą przyjmowanemu często bez zastrzeżeń binarnemu podziałowi dziedziny na literatury brytyjską i amerykańską ${ }^{70}$. Rzeczywiście na większości wydziałów anglistyki w Stanach Zjednoczonych literacka materia wciąż jest dzielona na amerykańską i brytyjską, przy czym pozostawia się pewną przestrzeń na „literaturę angielską inną niż amerykańska i brytyjska" - jak brzmi wiele odsłaniająca nazwa nadana przez wydział Modern Language Association of America temu bezsprzecznie transnarodowemu obszarowi. Natomiast w miarę odchodzenia od paradygmatu jednonarodowego, gdy tożsamościowe sposoby konstruowania wiedzy zostaną poddane zintensyfikowanej analizie, a postkolonialne i globalne studia zyskają większą siłę oddziaływania, anglistyka i inne dyscypliny humanistyczne będą lepiej sobie radzić z projektowaniem i definiowaniem modeli międzynarodowego, wyobrażeniowego obywatelstwa, które jest mobilne, ambiwalentne i wieloaspektowe.

${ }^{68}$ S. Rushdie, In Good Faith, [w:] tegoż, Imaginary Homelands: Essays and Criticism 1981-1991, London 1991, s. 394.

${ }^{69}$ T.S. Eliot, Gerontion, przeł. C. Miłosz, [w:] tegoż, Wybór poezji, dz. cyt., s. 60.

${ }^{70}$ M. McGill, Introduction: The Traffic in Poems, [w:] The Traffic in Poems: Nineteenth-Century Poetry and Transatlantic Exchange, red. M. McGill, New Brunswick 2008, s. 2. 
Chociaż narodowe etykiety implikują odrębność i spójność, poeci konstruują i rekonstruują swe często szczelinowe (interstitial) obywatelstwo, jak zaobserwowaliśmy, poprzez formalne i ideologiczne przepisania, przekształcanie dźwięków i tropów, obejmujące wiele narodowości. Koncepcja poetyckiego obywatelstwa stwarza przestrzeń dla wierszy ukształtowanych zarówno przez niewolicjonalne dziedzictwo wyobrażeniowe, jak i podlegającą wyborowi tożsamość konstruowaną w poprzek granic narodowych - dogodniejszą niż normy ustalone na podstawie orzecznictwa politycznego i miejsca narodzin (demos) albo pokrewieństwa (ethnos). Kiedy czynni poeci konfrontują się ze sztywnymi granicami narodów i państw na lotniskach i w punktach kontrolnych, na niewiele zdaje im się, że praktykują podróżną poezję, że są obywatelami wyobrażeniowych sieci skonstruowanych przez międzynarodowe lektury i przepisania. Nie ulega jednak wątpliwości, że każdy z nas, pracujących w dziedzinie anglistyki powinien zrobić wszystko, co w jego mocy, by oddzielić się od tych praktyk dyscypliny, które definiują podmiot, opierając się na granicach terytorialnych podlegających nadzorowi urzędników imigracyjnych.

Transnacjonalizm nie jest, przyznaję, immanentnie emancypacyjny, tak jak nacjonalizm nie zawsze jest reakcyjny. U zarania dekolonizacji w Kenii, pod koniec lat 60. XX wieku Ngũgĩ wa Thiong'o w pamiętny sposób przewodził ruchowi dążącemu do rozwiązania Wydziału Anglistyki Uniwersytetu w Nairobi i utworzenia w jego miejsce Wydziału Literatury i Języków Afrykańskich. W świetle imperialistycznego odseparowania afrykańskiej ludności od lokalnych języków i kultur wspieranie nacjonalizacji badań literackich - na wzór nacjonalizacji zasobów naturalnych w obrębie dekolonizującego się świata - było uzasadnione, nawet jeśli instytucjonalna reforma oznaczała odtworzenie w negatywie brytyjskich imperialistycznych założeń dotyczących literatury i narodowości ${ }^{71}$. Wszystko wskazuje na to, że badania literackie w najsilniejszych obecnie narodach powinny zwrócić się w przeciwnym kierunku. Osobiście piszę z perspektywy początkowych lat XXI wieku amerykańskiej akademii, w momencie, gdy najbardziej konsekwentnym nacjonalizmem świata jest ten amerykański, gdy hipotezy dotyczące cywilizacyjnych różnic stanowią czasem poręczenie w obrębie dyskursu politycznego czy nawet dla zamiarów amerykańskich sił zbrojnych działających za granicą. W tych warunkach i w szerszych okolicznościach postzimnowojennej hegemonii Stanów Zjednoczonych pożytek płynący z dekonstrukcji jednonarodowych paradygmatów i uwidocznienie sieci dialogujących powiązań, które je podważają oraz z spluralizowania i skreolizowania naszych modeli kultury i obywatelstwa nie powinien być bagatelizowany. „Rzecz w tym - jak pisze Edward Said - że jesteśmy wzajemnie ze sobą powiązani na sposoby, o jakich większość narodowych systemów edukacji nawet nie marzyła. Dostosowanie wiedzy o sztuce i nauce do owych integrujących realiów jest, jak wierzę, intelektualnym i kulturalnym wyzwaniem chwili"72. Zniuansowany obraz międzynarodowych i międzycywilizacyjnych (cross-civilizational) aliansów i napięć jest dziś wyjątkowo potrzebny, zaś zdenacjonalizowane dyscypliny humanistyczne mogą pomóc go zagwarantować, mimo ograniczonego pozainstytucjonalnego zasięgu badawczego. Jak udowodniły przykłady skomplikowanych powiązań na pozór przeczących sobie oddziaływań i opowieści oraz polifoniczne nawarstwienie idiomów i ideologii w poszczególnych utwo-

\footnotetext{
${ }^{71}$ Zob. A.O. Amoko, The Problem with English Literature: Canoncity, Citizenship, and the Idea of Africa, „Research in African Literatures” 32, nr 4, 2001, s. 19-43 i S. Gikandi, Globalization and the Claims of Postcoloniality, dz. cyt.

${ }^{72}$ E. Said, Kultura i imperializm, przeł. M. Wyrwas-Wiśniewska, Kraków 2009, s. 19.
} 
rach Yeatsa czy Eliota, Loy czy Toomera, Aghy Shahida Alego czy Lorny Goodison, poetycki transnacjonalizm może pomóc nam zarówno w zrozumieniu świata, którego kulturowe granice są przepuszczalne, jak i w odczytaniu nas samych - obdarzonych wyobraźnią obywateli światów, które bezustannie przenikają się, krzyżują i spotykają.

przekład z języka angielskiego: Iwona Ostrowska 


\section{S£OWA KLUCZOWE:}

globalizm

$$
\text { poetyka }
$$

\section{kultura narodowa}

transnarodowość

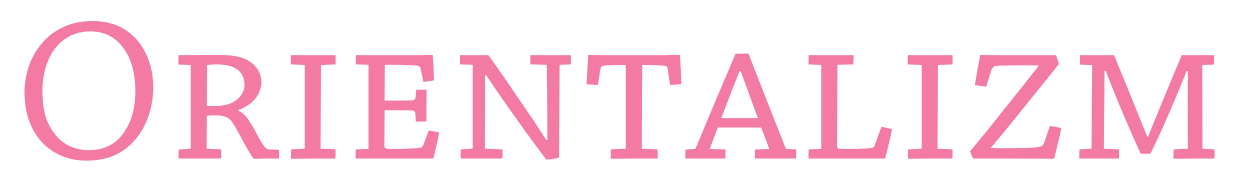




\section{transnarodowa}

\section{NOTA O AUTORzE:}

Jahan Ramazani, profesor na Uniwersytecie w Virginii oraz autor pięciu książek: Poetry and Its Others: News, Prayer, Song, and the Dialogue of Genres; A Transnational Poetics (2009), za którą otrzymał w 2011 Nagrodę Harry'ego Levina Amerykańskiego Stowarzyszenia Komparatystycznego dla najlepszej książki z zakresu komparatystycznej historii literatury opublikowanej w latach 2008-2010; The Hybrid Muse: Postcolonial Poetry in English (2001); Poetry of Mourning: The Modern Elegy from Hardy to Heaney (1994), która znalazła się w finale Nagrody Narodowego Stowarzyszenia Krytyków Literackich; Yeats and the Poetry of Death: Elegy, Self-Elegy, and the Sublime (1990). Jahan Ramazani jest również współredaktorem najnowszych wydan The Norton Anthology of Modern and Contemporary Poetry (2003) oraz The Norton Anthology of English Literature (2006, 2012), a także redaktorem współpracującym The Princeton Encyclopedia of Poetry and Poetics (2012). Jest członkiem Guggenheim Fellowship, NEH Fellowship, otrzymał Stypendium Rhodes, Nagrodę MLA Williama Riley’a Parkera oraz Nagrodę Thomasa Jeffersona, najważniejsze wyróżnienie przyznawane na University of Virginia. 